\title{
THE IMPACT OF CAPITAL STRUCTURE ON BANK PERFORMANCE: GMM ESTIMATION FOR THE CASE OF VIETNAM
}

\author{
DOI: 10.17261/Pressacademia.2021.1426 \\ PAP- V.13-2021(15)-p.73-83
}

Thu Thuy Nguyen ${ }^{1}$, Trung Dung Nguyen ${ }^{2}$, Thuy Tien Dinh ${ }^{3}$, Khanh Linh Vu ${ }^{4}$

${ }^{1}$ Foreign Trade University, Faculty of Banking and Finance, Department of Money and Banking, Hanoi, Vietnam. thuthuynguyen@ftu.edu.vn, ORCID: 0000-0001-8001-037X

${ }^{2}$ Foreign Trade University, Hanoi, Vietnam. dunght211089@gmail.com, ORCID: 0000-0002-5425-4511

${ }^{3}$ Foreign Trade University, Faculty of Banking and Finance, Department of Corporate Finance, Hanoi, Vietnam. tiendt@ftu.edu.vn, ORCID: 0000-0002-8713-8322

${ }^{4}$ Foreign Trade University, Faculty of Banking and Finance, Department of Money and Banking, Hanoi, Vietnam. khanhlinhvu@ftu.edu.vn, ORCID: 0000-0003-0468-1029

\section{To cite this document}

Nguyen, T.T., Nguyen, T.D., Dinh, T.T., Vu, K.L., (2021). The impact of capital structure on bank performance: GMM estimation for the case of Vietnam, PressAcademia Procedia (PAP), V.11, 73-83.

Permanent link to this document: http://doi.org/10.17261/Pressacademia.2021.1426

Copyright: Published by PressAcademia and limited licensed re-use rights only.

\section{ABSTRACT}

Purpose- Bank managers have recently focused more on capital structure with the aim of achieving optimal financial cost allocation in bank operations in order to enhance their performance.

Methodology- Employing the database of 28 Vietnamese commercial banks during the period 2010-2019, this paper investigates the impact of capital structure on bank performance.

Findings- By applying Pooled OLS, FEM and REM regression models, combined with SYS-GMM technique to fix some diagnose problems as well as endogeneity phenomena, the empirical findings reveal that capital structure (measured by total debt to assets and debt to equity ratios) negatively and significantly influences the performance of selected commercial banks (measured by ROA and ROE). Meanwhile, most of control variables (bank size, non-performing loan, liquidity, and GDP growth rate) represent significant and positive relationships with bank performance, except for the negative impact of operating cost rate.

Conclusion- Regarding these outcomes, some implications are suggested to policy makers and bank managers to improve bank performance, subsequently to enhance the stability of the Vietnamese banking system - especially under the current uncertain economic conditions.

Keywords: Capital structure, bank performance, Vietnamese commercial banks, bank stability, GMM

JEL Codes: G21, G32, L25

\section{INTRODUCTION}

An increasingly essential role of banks in the financial system is undeniable, hence the improvement of bank performance has been targeted as the major concentration by many bank managers as well as regulators. Considering many factors affecting bank performance, also taking into account the spreading of panics in global banking system, capital structure has recently attracted the attention in the literature abound. The optimum capital structure can be considered as a useful buffer to help banks avoid financial exhaustion when a crisis occurs. The Basel Committee made amendments on Basel standards (namely Basel $3^{1}$ ) to regulate the minimum financial leverage ratio, taking into account both on-balance sheet and off-balance sheet activities of financial institutions. The financial institutions are also required to add extra capital to protect depositors and to mitigate unexpected losses when risks occur. Determining the impact of capital structure on bank performance may provide significant benefits to policymakers, administrators, and shareholders by predicting and minimizing potential risks related to financial decisions in banking activities, thereby contributing to improve bank performance and to maximize bank value as well as the value of assets for shareholders.

\footnotetext{
${ }^{1}$ https://www.bis.org/bcbs/basel3
} 
Regarding capital structure issue, there are some well-known studies, such as the "irrelevance theory of capital structure" - introduced by Modigliani and Miller (M\&M theorem) $(1958,1963)$, the pecking order theory (Myers, 1984, Myers \& Majluf, 1984), the trade off theory (Kraus \& Litzenberger, 1973, Jensen \& Meckling, 1976), and "market timing theory of capital structure" (Baker and Wurgler, 2002). However, their applications have mainly focused on the scope of non-bank firms. Bank capital structure can be approached in the different way due to its own distinctive characteristics and it generally subjects to heavier regulations. There are a number of studies in the literature on the relationship between capital structure and bank performance (such as Saeed el al., 2013, Siddik et al., 2017, El-Chaarani \& El-Abiad, 2019); nonetheless, it has been still limited and reveals no consistent results, especially for the Vietnamese banking system. Therefore, this paper focuses on analyzing the impact of capital structure (measured by total debt to total assets and total debt to equity) and selected control variables (including bank size, operating cost rate, liquidity, economic growth, and inflation) on bank performance (measured by ROA and ROE). The regression models and GMM estimation will be applied to the database gathered from 28 Vietnamese commercial banks during the period 2010-2019.

\section{LITERATURE REVIEW}

A number of theories on modern capital structure have been employed for many empirical studies, covering the impact of capital structure on bank performance in many countries over the world. Although some of them revealed their significant relationship (such as Pinto et al., 2017; El-Chaarani and El-Abiadn, 2019), the results have been inconclusive.

The first group of papers agrees with the results about the negative impact of capital structure on bank performance. Goyal (2013) investigated the effect of capital structure on the performance of 19 listed Indian banks for the period 2008-2012. The outcomes showed that debt to total assets ratio, debt to capital ratio negatively correlated with ROA, ROE and EPS. Note that profitability ratios, including return on total assets (ROA), return on equity (ROE), and return on equity (EPS), are mainly used to represent for bank performance in many studies. The negative impact of capital structure on bank performance was also demonstrated in many others, such as the study of Ronoh (2015) for listed commercial banks in Kenya during the period 2009-2013; Birru (2016) for commercial banks in Ethiopia during 2011-2015; Pinto and Quadras (2016) for Indian banks for the period 2006-2014; Siddik et al. (2017) for 22 banks in Bangladesh in the period 2005 - 2014; and Nwude and Anyalechi (2018) for banks in Nigeria from 2001 to 2013. Not only for traditional commercial banks, Pratomo and Ismail (2006) analyzed 15 Islamic banks in Malaysia from 1997 to 2004 and proved that a high leverage ratio or a lower equity ratio helped banks reduce agency costs, thereby increasing profitability. Although the effect was mutual, the result was not marked for large banks.

Conversely, the positive impact of capital structure on bank performance has been found in Saeed et al. (2015). While using ROA, ROE and EPS to measure the performance of Pakistani banks listed on Karachi stock exchange from 2007 to 2011, the outcomes of multiple regression model suggested that capital structure ratios (including long-term debt to capital, short-term debt to capital and total debt to capital) positively related with bank performance.

Meanwhile, a number of other studies have shown the dissimilar effects of capital structure on different indicators of bank performance. One typical research was from Hutchison and Cox (2006). When testing the agency cost theory on US banks in two periods 1983-1989 and 1996-2002, the results demonstrated that financial leverage has a positive effect on ROE but negative effect on ROA. Similar findings were found in Birrue (2016) when analyzing the impact of capital structure on commercial bank performance in Ethiopia for 5 years from 2011 to 2015. The paper showed evidence for negative impacts of debt-to-equity ratio, bank size, and tangible assets, but a positive impact of debt ratio on ROA. Furthermore, ROE was influenced positively by debt ratio and debt-to-equity ratio but negatively by size and tangible assets.

Expanding the research scope to the group of Middle Eastern countries (covering 143 banks), El-Chaarani and El-Abiadn (2019) represented the fluctuation of banks' capital structure in banks) for the period 2011-2016 which could be explained by the economic features of this region. The results demonstrated the significant linkage between capital structure (measured by total debt to total assets and total shortterm debt to total assets) and bank performance. The impact, however, was negative for ROE but positive for ROA. In addition, an increase in total long-term debt to total assets significantly led to an increase in ROA, but not in ROE. Except for bank size (which had a positive impact), the outcomes could not show a significant impact from liquidity and asset growth rate on profitability ratios. Last but not least, the paper suggested that capital structure was not determined by profitability ratios but national and international regulatory framework.

When studying 8 commercial banks in Vietnam for the period 2003-2008, Nguyen and Hoang (2009) showed the evidence for the impact of capital structure as well as selected factors (namely bank size and governance capacity) to bank performance by using multivariate regression model. Using absolute value for variables' measurement, equity size and total revenue were proved to have positive relationship with operating profit. In contrast, total assets, capital adequacy ratio (CAR) and total costs negatively related to operating profit. Similar findings were found when using financial ratios, as ROA was positively influenced by capital structure (equity to total assets ratio), but negatively affected by costs to income ratio and capital adequacy ratio (CAR).

Phan and Phan (2013) analyzed the determinants of bank performance for the case of 28 Vietnamese commercial banks from 2005 to 2012 , taking into account capital structure which was measured by mobilized capital to total assets ratio. This ratio was found to have adverse influence on bank performance, consistent with the result of Nguyen and Hoang (2009). Besides, the random effects model showed that it was not market share but the level of market concentration that had a positive impact on bank performance (measured by ROAA and ROAE). Then bank performance could be enhanced if increasing bank size and decreasing inflation.

With the same interest of research, Nguyen and Nguyen (2020) re-evaluated the factors affecting business performance for the case of 9 commercial banks which had merger and acquisition activities from 2008 to 2018. The outcomes from the fixed effects and random effects models suggested that capital structure (debt-to-equity ratio) has a negative effect on ROA but has a positive effect on ROE. This conclusion supported earlier findings of Hutchison and Cox (2006) and El-Chaarani and El-Abiadn (2019). 
It can be concluded that most of the empirical results have been able to demonstrate the crucial influence of capital structure on the performance of commercial banks. However, a confirmation of this relationship as positive or negative has been yet indecisive, either in the world or for the case of Vietnam. Under the current context of risky and fragile global economy, especially banking system in emerging economies like Vietnam, this paper has inherited prior studies' methods and applied SYS-GMM technique to find out the impact of capital structure on the performance of 28 commercial banks for the period from 2010 to 2019.

\section{DATA AND METHODOLOGY}

\section{Data Collection}

The panel data used in this paper is collected from the audited financial statements and annual reports of 28 Vietnamese commercial banks for 10-year period from 2010 to 2019. Thus, the total number of observations is 280 . The macroeconomic data is gathered from the General Statistics Office of Vietnam $(\mathrm{GSO})^{2}$ and the Ministry of Finance of Vietnam (MOF) ${ }^{3}$ in order to ensure the reliability as well as the validity.

\section{Selection and Measurement of Variables}

Inheriting from prior research along with the current situation of the Vietnamese banking system, this paper uses two variables to measure the profitability of banks, including return on total assets (ROA) and return on equity (ROE), which represents for bank performance. Two variables, debt to total assets (DTA) and debt to equity (DTE), are used to represent bank capital structure. The selected control variables comprise of bank size (SIZE), non-performing loan (NPL), liquidity ratio (LIQ), economic growth (GDP) and inflation (INF).

\section{Bank performance: $R O A, R O E$.}

ROA and ROE are both important financial indicators that reflect the results of a bank's operation efficiency. The higher ROA banks achieve, the better its capacity to manage a reasonable asset structure as well as its flexibility to maneuver among asset classes in response to fluctuations in the economy (Saeed et al., 2013, Goyal, 2013); whereas lower ROA may reflect an inactive lending or investment policy or excessive bank operating costs (Goyal, 2013, Pinto and Quadras, 2016, Siddik et al., 2017). Meanwhile, ROE is an interest of shareholders since it measures the profitability generated by common shareholders' investment (Salim et al., 2012, Goyal, 2013, Hasan et al., 2014). According to Hasan et al. (2014) and Siddik et al. (2017), a higher ROE means that the bank has been used shareholders' investment or allocates between equity capital and borrowings more efficiently.

Bank capital structure: DTA, DTE.

In prior empirical studies, many factors correlated with debt ratio have been identified through two theoretical models of trade-off and pecking order (Saeed et al., 2013, Ronoh, 2015). Bank capital structure is typically measured by debt-to-assets ratio and debt-to-equity ratio. Many findings supported for the view that the capital structure negatively affects the performance of banks (Goyal, 2013, Birru, 2016, Siddik et al., 2017), which means banks have not utilised the competitive advantage of financial leverage to boost up their profit margin or they suffer high capital mobilization costs that negatively affect the efficiency of capital use and then reducing the profitability.

Hypotheses H1-H4: Capital structure (DTA, DTE) has a negative and statistically significant relationship with bank performance (ROA, ROE).

Control Variables: SIZE, NPL, CIR, LIQ, GDP, CPI

Firm size, measured by natural logarithm of total assets, is commonly used to study the relationship between capital structure and firm performance (Zeitun and Tian, 2007). Larger banks are better managed, benefiting from economies of scale and high technology; therefore, bank size and financial performance are positively correlated. (Curi et al., 2015; Berger et al., 2010).

Hypothesis H5: Bank size has a positive and statistically significant relationship with bank performance (ROA, ROE).

Low bank credit quality is commonly represented by high non-performing loan ratio, which consequently has an adverse influence on bank performance. Agree with the findings of Lepetit et al. (2008), this paper builds up a hypothesis that non-performing loan and profitability are negatively related.

Hypothesis H6: Non-performing loan ratio (NPL) has a negative and statistically significant relationship with bank performance (ROA, ROE).

Lepetit et al. (2008) disclosed that if expenses increase faster than income from operations, it can reduce the bank's business efficiency. Maudos and Solís (2009) and Trinugroho et al. (2014) also agreed that high operating costs to income ratio means that the bank is inefficient or has poor management quality.

Hypothesis H7: Operating cost to income ratio (CIR) has a negative and statistically significant relationship with bank performance (ROA, $R O E)$.

In measure bank liquidity, the article uses loan-to-deposit ratio which represents the ability of banks to fulfil requirements about cash from customers. If this ratio is low, commercial banks tend to fail to achieve expected earnings. Some empirical studies show that higher liquidity leads to greater profitability of commercial banks (Demirgüç-Kunt and Huizinga, 2010, Norden and Weber, 2010).

${ }^{2}$ https://www.gso.gov.vn/en/homepage/

${ }^{3}$ https://www.mof.gov.vn 
Hypothesis H8: Operating cost to income ratio (CIR) has a positive and statistically significant relationship with bank performance (ROA, ROE).

Acknowledging the sensitivity of banks' activities to economic environment, this paper selects two representatives for macroeconomic variables which are economic growth (GDP growth rate) and inflation (CPI) (Abdel-Hameed, 2003, Kabir and Abdel-Hameed, 2003, Flamini et al., 2009). A favorable macroeconomic environment will promote economic growth, and hence it is expected to have a positive effect on bank profitability (Davydenko, 2010, Obayumi, 2013). Meanwhile, inflation may positively stimulus the profitability of banks if it is predictable, accordingly banks can make appropriate interest rate adjustments to keep their revenue increasing (Flamini et al., 2009, Ongore and Kusa, 2013). For Vietnam, the inflation policy has been effectively implemented by the government, so the paper expects the inflation have a positive impact on the bank performance.

Hypothesis H9-10: Economic growth (GDP) and inflation (CPI) has a negative and statistically significant relationship with bank performance (ROA, ROE).

\section{Specification of models}

Mainly studies on capital structure of commercial banks are carried out in emerging and developing economies, applying trade-off theory and pecking order theory to demonstrate that capital structure has an impact on efficiency of banking business.

\section{Bank performance $=f$ (capital structure, control variables)}

Inheriting and developing research models of Goyal (2013), Birru (2016), Pinto and Quadras (2016), Siddik et al. (2017) for the case of Vietnam's banking industry, the research model is given as follows:

$$
Y_{i, t}=\beta_{0}+\beta_{1} D T A_{i, t}+\beta_{2} D T E_{i, t}+\sum_{s=3}^{8} \beta_{s} \lambda_{i, t}+\varepsilon_{i, t}
$$

Where:

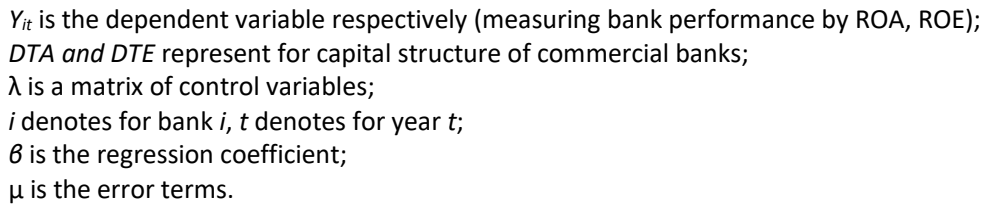

The variables are described in the following table:

Table 1: Research Variables and Expected Signs

\begin{tabular}{|c|c|c|c|c|c|}
\hline Variable & Explanation & Measurement & Expected sign & $\begin{array}{l}\text { Empirical research } \\
\text { sources }\end{array}$ & Data source \\
\hline \multicolumn{6}{|c|}{ Operational efficiency } \\
\hline ROA & Return on asset & Net income/Total assets & & $\begin{array}{l}\text { Goyal (2013), } \\
\text { Siddik et al. (2017) }\end{array}$ & $\begin{array}{l}\text { Financial } \\
\text { Statements }\end{array}$ \\
\hline ROE & Return on equity & $\begin{array}{l}\text { Net income/ } \\
\text { Shareholders'equity }\end{array}$ & & $\begin{array}{l}\text { Goyal (2013), } \\
\text { Siddik et al. (2017) }\end{array}$ & $\begin{array}{l}\text { Financial } \\
\text { Statements }\end{array}$ \\
\hline \multicolumn{6}{|c|}{ Capital Structure } \\
\hline DTA & Debt ratio & Total debt/Total assets & $(-)$ & $\begin{array}{l}\text { Goyal (2013), Birru } \\
\text { (2016), Siddik et al. } \\
\text { (2017) }\end{array}$ & $\begin{array}{l}\text { Financial } \\
\text { Statements }\end{array}$ \\
\hline DTE & $\begin{array}{l}\text { Debt-to-equity } \\
\text { ratio }\end{array}$ & Total debt/Total equity & $(-)$ & $\begin{array}{l}\text { Saeed et al. (2013) } \\
\text { Birru (2016) }\end{array}$ & $\begin{array}{l}\text { Financial } \\
\text { Statements }\end{array}$ \\
\hline \multicolumn{6}{|c|}{ Control variables } \\
\hline SIZE & Bank size & The natural logarithm of total assets & $(+)$ & $\begin{array}{l}\text { San \& Heng (2012), } \\
\text { Dawood (2014), }\end{array}$ & $\begin{array}{l}\text { Financial } \\
\text { Statements }\end{array}$ \\
\hline NPL & $\begin{array}{l}\text { Non-performing } \\
\text { loan ratio }\end{array}$ & $\begin{array}{l}\text { Non-performing loan/ total gross } \\
\text { loans }\end{array}$ & $(-)$ & $\begin{array}{l}\text { Lepetit et al. (2008) } \\
\text { Porter \& Chiou } \\
\text { (2012) Goyal } \\
(2013)\end{array}$ & $\begin{array}{l}\text { Financial } \\
\text { Statements }\end{array}$ \\
\hline LIQ & Liquidity ratio & Loans/deposits & + & $\begin{array}{l}\text { Demirgüç-Kunt \& } \\
\text { Huizinga, (2010); } \\
\text { Norden \& Weber } \\
\text { (2010) }\end{array}$ & $\begin{array}{l}\text { Financial } \\
\text { Statements }\end{array}$ \\
\hline $\mathrm{CIR}$ & $\begin{array}{l}\text { Cost to income } \\
\text { ratio }\end{array}$ & Cost/Income & - & $\begin{array}{l}\text { Lepetit et al. } \\
\text { (2007); Maudos \& } \\
\text { Solís (2009) }\end{array}$ & $\begin{array}{l}\text { Financial } \\
\text { Statements }\end{array}$ \\
\hline
\end{tabular}




\begin{tabular}{|l|l|l|l|l|l|}
\hline GDP & GDP growth & GDP Annual growth rate & $(+)$ & $\begin{array}{l}\text { Davydenko (2010), } \\
\text { Aremu \& Ayanda } \\
(2013)\end{array}$ & GOS, WB \\
\hline CPI & Inflation rate & CPI Annual growth rate & $(+)$ & $\begin{array}{l}\text { Ongore \& Kusa } \\
\text { (2013), Sufian \& } \\
\text { Chong (2008) }\end{array}$ & GOS, WB \\
\hline
\end{tabular}

Source: Synthesis of previous studies

\section{Techniques of Data Analysis}

The study conducts regression estimations covering Pooled OLS, random effects model (REM), and fixed effects model (FEM) to evaluate the effects of capital structure on the performance of 28 commercial banks over the period from 2010 to 2019 . The two-step system GMM is subsequently proposed to deal with heteroscedasticity and endogenous problem (Arellano and Bover, 1995, Blundell and Bond, 1998).

\section{EMPIRICAL FINDINGS}

The average ROA of commercial banks was $0.72 \%$, ranging from $-5.51 \%$ to $2.64 \%$; while the average ROE is $8.71 \%$, ranging from $-82 \%$ to $26.82 \%$. Observing capital structure, debts account for $91.9 \%$ of total assets on average, and outstanding loans are 12.09 times higher than total equity. Liquidity ratio is averaged at $86.32 \%$, showing that the liquidity of banks' capital is high and that the purpose of capital mobilisation is maximised for traditional credit activities of commercial banks. The average NPL ratio of $2.45 \%$ is below the SBV's benchmark of $3 \%$, suggesting that bad loans have been under control. In spite of a challenging global economic environment, the Vietnam's economy has maintained good growth during the period 2010-2019, with the GDP growth rate ranged from 5.25\% to $7.08 \%$, thanks to high domestic consumption and export-oriented industrialisation. Inflation has been also well controlled by synchronously implementing monetary policy, credit policy and fiscal policy as well as a mechanism of flexible coordination between fiscal policy and monetary policy. Table 2 provides the basic statistic features of the data, including the mean, minimum and maximum values.

Table 2: Descriptive Statistics

\begin{tabular}{|l|c|l|l|l|}
\hline Variables & Observation & Mean & Minimum & Maximum \\
\hline ROA & 280 & 0.0072 & -0.0551 & 0.0267 \\
\hline ROE & 280 & 0.0871 & -0.8200 & 0.2682 \\
\hline DTA & 280 & 0.9119 & 0.7446 & 0.9710 \\
\hline DTE & 280 & 12.0923 & 2.9156 & 33.4526 \\
\hline NPL & 280 & 0.0245 & 0.0001 & 0.1140 \\
\hline CIR & 280 & 0.5426 & 0.2798 & 0.9274 \\
\hline LIQ & 280 & 0.8632 & 0.3633 & 1.7893 \\
\hline SIZE & 280 & 18.5379 & 15.9227 & 21.1220 \\
\hline GDP & 280 & 0.0631 & 0.0525 & 0.0708 \\
\hline CPI & 280 & 0.0618 & 0.0088 & 0.1868 \\
\hline
\end{tabular}

Source: Calculations from Stata 14

The correlation matrix is a simple test to examine the strength of the linear association between a pair of variables. Table $\mathbf{3}$ shows the correlation coefficients of all of the variables. The result reveals that the correlations between the independent variables are mostly statistically insignificant.

Table 3: Correlation Matrix

\begin{tabular}{|c|c|c|c|c|c|c|c|c|c|c|}
\hline & ROA & ROE & DTA & DTE & NPL & CIR & SIZE & LIQ & GDP & CPI \\
\hline ROA & 1 & & & & & & & & & \\
\hline ROE & 0.8801 & 1 & & & & & & & & \\
\hline DTA & -0.2507 & 0.1406 & 1 & & & & & & & \\
\hline DTE & -0.2444 & 0.1323 & 0.8661 & 1 & & & & & & \\
\hline NPL & 0.0172 & -0.0694 & -0.1423 & -0.1171 & 1 & & & & & \\
\hline CIR & -0.6456 & -0.6026 & 0.0535 & 0.0287 & 0.1394 & 1 & & & & \\
\hline
\end{tabular}




\begin{tabular}{|l|l|l|l|l|l|l|l|l|l|l|}
\hline SIZE & 0.129 & 0.4004 & 0.6647 & 0.6555 & -0.1728 & -0.2979 & 1 & & & \\
\hline LIQ & 0.2723 & 0.2288 & -0.116 & -0.0627 & -0.0055 & -0.257 & 0.0199 & 1 & & \\
\hline GDP & 0.0923 & 0.1837 & 0.2806 & 0.2978 & -0.2706 & -0.182 & 0.2415 & 0.2013 & 1 & \\
\hline CPI & 0.1271 & 0.0077 & -0.2388 & -0.2051 & 0.164 & -0.1508 & -0.2414 & 0.1921 & -0.3812 & 1 \\
\hline
\end{tabular}

Source: Calculations from Stata 14

The study applies various forms of regression models, including Pooled OLS, random effects model (REM), fixed effects model (FEM), to evaluate the impact of capital structure (measured by debt to assets ratio (DTA) and debt to equity ratio (DTE)) on the performance of 28 commercial banks (measured by ROA and ROE). The results of Hausman test and F-test in Table $\mathbf{4}$ prove that FEM is the most appropriate to the selected database.

Table 4: Regression Results for the Impacts of Capital Structure on Vietnamese Bank Performance

\begin{tabular}{|c|c|c|c|c|c|c|}
\hline \multirow{2}{*}{ Variables } & \multicolumn{3}{|c|}{ ROA } & \multicolumn{3}{|c|}{ ROE } \\
\hline & Pooled & FEM & REM & Pooled & FEM & REM \\
\hline \multirow[t]{2}{*}{ DTA } & $-0.0277^{*}$ & $-0.0331^{* *}$ & $-0.0291^{*}$ & 0.214 & 0.123 & 0.195 \\
\hline & {$[-1.71]$} & {$[-2.01]$} & {$[-1.80]$} & [0.98] & {$[0.52]$} & {$[0.88]$} \\
\hline \multirow[t]{2}{*}{ DTE } & $-0.000350 * * *$ & $-0.000299 * *$ & $-0.000288^{* *}$ & -0.00155 & $9.65 \mathrm{E}-05$ & -0.00098 \\
\hline & {$[-2.87]$} & {$[-2.13]$} & {$[-2.24]$} & {$[-0.94]$} & {$[0.05]$} & {$[-0.57]$} \\
\hline \multirow[t]{2}{*}{ NPL } & $0.0432 * *$ & $0.0679 * * *$ & $0.0629 * * *$ & 0.309 & $0.636^{* *}$ & $0.439 *$ \\
\hline & {$[2.22]$} & [3.38] & [3.23] & [1.18] & {$[2.20]$} & [1.65] \\
\hline \multirow[t]{2}{*}{$\mathrm{CIR}$} & $-0.0267 * * *$ & $-0.0311 * * *$ & $-0.0286 * * *$ & $-0.321 * * *$ & $-0.360 * * *$ & $-0.330 * * *$ \\
\hline & {$[-10.40]$} & {$[-10.85]$} & {$[-10.61]$} & {$[-9.30]$} & {$[-8.71]$} & {$[-9.14]$} \\
\hline \multirow[t]{2}{*}{ SIZE } & $0.00138^{* * *}$ & $0.00436^{* * *}$ & $0.00163^{* * *}$ & $0.0170^{* * *}$ & $0.0412^{* * *}$ & $0.0174 * * *$ \\
\hline & [3.54] & {$[4.66]$} & [3.31] & [3.26] & [3.05] & [2.94] \\
\hline \multirow[t]{2}{*}{ LIQ } & $0.00274 *$ & $0.00632^{* * *}$ & $0.00478^{* * *}$ & $0.0426^{* *}$ & $0.0915^{* * *}$ & $0.0559 * *$ \\
\hline & {$[1.71]$} & [3.27] & {$[2.74]$} & [1.97] & [3.29] & {$[2.43]$} \\
\hline \multirow[t]{2}{*}{ GDP } & 0.0782 & -0.0762 & 0.0379 & 0.21 & -1.375 & -0.00839 \\
\hline & [1.33] & {$[-1.26]$} & {$[0.67]$} & {$[0.27]$} & {$[-1.58]$} & {$[-0.01]$} \\
\hline \multirow[t]{2}{*}{ CPI } & 0.00132 & 0.00542 & -0.00143 & -0.0534 & -0.0428 & -0.0739 \\
\hline & [0.19] & {$[0.74]$} & {$[-0.21]$} & {$[-0.57]$} & {$[-0.41]$} & {$[-0.80]$} \\
\hline \multirow[t]{2}{*}{ Const. } & 0.0173 & -0.0256 & 0.0146 & -0.286 & $-0.600 * *$ & -0.277 \\
\hline & [1.23] & {$[-1.36]$} & [1.01] & {$[-1.51]$} & {$[-2.22]$} & {$[-1.43]$} \\
\hline $\mathbf{N}$ & 280 & 280 & 280 & 280 & 280 & 280 \\
\hline The number of groups & 28 & 28 & 28 & 28 & 28 & 28 \\
\hline $\mathbf{R}^{2}$ & 0.51 & 0.533 & 0.5089 & 0.431 & 0.366 & 0.347 \\
\hline F-test & 35.28 & 34.85 & & 25.63 & 17.57 & \\
\hline
\end{tabular}

Source: Calculations from Stata 14

Nevertheless, the FEM diagnoses to heteroskedasticity and autocorrelation issues. Hence, the paper proposes two-step system GMM solve these problems (Arellano and Bover, 1995, Blundell and Bond, 1998). 
Table 5: The Evaluation of GMM Model for the Impact of Capital Structure on Vietnamese Commercial Banks' Performance

\begin{tabular}{|c|c|c|}
\hline Variable & ROA & ROE \\
\hline \multirow[t]{2}{*}{ DTA } & $-0.0534 * * *$ & $-0.299 * *$ \\
\hline & {$[-4.88]$} & {$[-2.22]$} \\
\hline \multirow[t]{2}{*}{ DTE } & $-0.000269 * *$ & 0.00134 \\
\hline & {$[-2.21]$} & {$[1.14]$} \\
\hline \multirow[t]{2}{*}{ NPL } & $0.0525^{* * *}$ & $0.255^{*}$ \\
\hline & [3.97] & [1.73] \\
\hline \multirow[t]{2}{*}{$\mathrm{CIR}$} & $-0.0261 * * *$ & $-0.331 * * *$ \\
\hline & {$[-9.28]$} & {$[-9.86]$} \\
\hline \multirow[t]{2}{*}{ SIZE } & $0.00177^{* * *}$ & $0.0197 * * *$ \\
\hline & {$[4.58]$} & {$[4.59]$} \\
\hline \multirow[t]{2}{*}{ LIQ } & $0.00200 * *$ & $0.0220^{*}$ \\
\hline & {$[2.04]$} & [1.95] \\
\hline \multirow[t]{2}{*}{ GDP } & $0.0682 * * *$ & 0.213 \\
\hline & [2.94] & {$[0.73]$} \\
\hline \multirow[t]{2}{*}{$\mathrm{CPI}$} & 0.000519 & 0.00724 \\
\hline & {$[0.10]$} & {$[0.10]$} \\
\hline \multirow[t]{2}{*}{ Const. (C) } & $0.0332^{* * *}$ & 0.121 \\
\hline & [3.12] & [1.18] \\
\hline Number of observations & 280 & 280 \\
\hline Number of groups & 28 & 28 \\
\hline AR (1) & $\begin{array}{l}-1.15 \\
(0.252) \\
\end{array}$ & $\begin{array}{l}-1.05 \\
(0.294) \\
\end{array}$ \\
\hline AR (2) & $\begin{array}{l}-1.54 \\
(0.125) \\
\end{array}$ & $\begin{array}{l}-0.98 \\
(0.325) \\
\end{array}$ \\
\hline Hansen & $\begin{array}{l}21.42 \\
(0.091) \\
\end{array}$ & $\begin{array}{l}15.45 \\
(0.348)\end{array}$ \\
\hline
\end{tabular}

$*, * *$, and ${ }^{* * *}$ denotes statistical significance at $1 \%, 5 \%$, and $10 \%$, respectively Source: Calculations from Stata 14

Hansen test (1982) is used to assess the fitness of variables and the research model. To test the autocorrelation problem, the study used the Arellano-Bond (AR) test. If the Hansen (1982) and AR(2) values of the model are statistically significant at $5 \%$, it can be concluded that the selected variables and the research model are applicable. The outcomes in Table 5 show that the Hansen and AR (2) values have $p>0.05$. Therefore, the selection of endogenous and instrumental variables is appropriate.

\section{Discussion of Empirical Findings}

Firstly, capital structure (DTA, DTE) negatively impacts business performance (ROA, ROE) of Vietnamese commercial banks, then hypotheses H1-H4 are accepted. These findings are consistent with previous studies such as Amidu (2007), Goyal (2013), and Siddik et al. (2017). The results are also applicable for the current situation in Vietnam, where the low financial autonomy of banks has negatively affected the efficiency of capital and asset use. In practice, bank assets (loans) are often financed by short-term liabilities, while the proportion of short-term liabilities accounts for more than three-quarters of the capital of banks. The issue of equity management is currently a problem in many commercial banks.

Secondly, non-performing loan ratio (NPL) has a positive influence in bank performance, then hypothesis $\mathrm{H} 5$ is rejected. Despite of an increase in bad debts, commercial banks have announced their growing profits. It contradicts the findings of Aggarwal and Jacques (2001), Lepetit et al. (2008), and Porter and Chiou (2012) while they argued that inefficient loans (high NPL ratio) could reduce asset quality and rapidly increase bank risk. Under the current context of the Vietnamese banking system, although non-performing loans increased due to not being effectively controlled, many banks have recorded positive revenues thanks to the effective implementation of cost reduction and diversification of revenue sources. 
Thirdly, cost to income ratio (CIR) has a negative relationship with the performance of commercial banks, then hypothesis $\mathrm{H} 6$ is accepted. This result is consistent with the results of Lepetit et al. (2007), when operating costs are much higher than the growth of earning assets and total liabilities, the banks' operation is inefficient and hence their profitability decreases. In fact, the increase of costs in many Vietnamese commercial banks is higher than the speed of operating expansion, leading to a negative impact on bank performance. Significant increases in operating expenses mainly come from human resource costs, depreciation expenses for infrastructure and information technology investment, and risk provision for bad debts.

Fourthly, liquidity ratio (LIQ) has a positive relationship with the performance of Vietnamese commercial banks, then hypothesis $\mathrm{H7}$ is accepted. The higher liquidity (LIQ) typically leads to higher profitability (as the results of Demirgüç-Kunt and Huizinga, 2010, Norden and Weber, 2010). In Vietnam, commercial banks who can maintain high liquidity are usually large commercial banks with capital from state. They are also better to cope with the increasingly competitive pressure in raising capital mobilization costs or reducing lending rates, thereby ensuring their ability to gain higher profitability.

Fifthly, bank size (SIZE) has a positive relationship with the performance of banks, then hypothesis H8 is accepted. Smirlock (1985) argued that the greater size can increase bank profitability since they take advantages of capital, human resources, operating network, cost management capacity and ability to cope with risks better than smaller banks. In Vietnam, the banks with the greatest market share and asset volume are currently Agribank, Vietcombank, BIDV, and Vietinbank, they are also leading in terms of profitability.

Sixthly, economic growth (GDP) has a positive impact on the business performance of banks, then hypothesis H9 is accepted (similar to the previous findings of Demirguc-Kunt and Huizinga, 1999, Bikker and Hu, 2002, Moulton, 2011). Although the global economy has recently faced many difficulties and challenges, a moderate high GDP growth rate can be maintained given strong domestic demand and exportoriented strategy in manufacturing. Together with the gradual economic growth, the significant contribution of total factor productivity (TFP) to GDP growth has created the impetus to increase operational efficiency in the Vietnamese banking system.

Finally, the empirical findings could not shown a statistically significant relationship between the inflation rate (CPI) and the performance of commercial banks, hence hypothesis $\mathrm{H1O}$ is rejected. Theoretically, the occurrence of inflation is typically considered as a sign of economic growth, hence indirectly promotes the development of commercial banks. However, like some previous empirical studies, this paper could not prove the significant influence of inflation on bank profitability (such as Naceur, 2003, Ramadan et al., 2011, Abugamea, 2018). The impact of inflation is only well-defined if it can be predicted precisely; however, it should be hard as the predictability of inflation relies on many different factors.

\section{CONCLUSION}

In order to fulfil the purpose of investigating the capital structure impact on bank performance, this paper employed Pooled OLS regression model, random effects model, and fixed effect model for the database gathered from 28 Vietnamese commercial banks during the 10-year period 2010-2019. Although FEM was proved to be the most appropriate for selected data, they diagnosed with autocorrelation and heteroskedasticity problems. The two-step SYS-GMM regression model was therefore proposed to take into account these issues as well as endogeneity. The empirical outcomes concluded that the capital structure and cost to income ratio negatively affect the performance of selected Vietnamese commercial banks. Meanwhile, except for inflation, other control variables (bank size, liquidity ratio, non-performing loan ratio, and economic growth) moved together with the bank performance.

Commercial banks are typically characterised with high debt to total assets as well as high debt to equity ratios in comparison with nonbanks, while the major source of their debt is from customer deposits. For that reason, it is challenging to develop a theory of optimal capital structure for banking industry as well as to help banks take advantage of the benefits of optimal capital structure. The findings of this paper, therefore, contribute to the existing literature and propose some recommendations for bank managers, policy makers, and bank shareholders to assess bank performance better when banks decide to change their capital structure.

(i) Constructing a capital structure management mechanism according to international rules and practices to increase operational safety as well as overcome system instability and avoid future failures.

(ii) Preparing long-term strategy to increase equity in order to enhance financial capacity to meet the requirements on capital adequacy ratio and to adapt with the expansion of business activities.

(iii) Improving the efficiency of debt management by quickening the settlements of bad debts and planning different debt settlement plans such as asset liquidation, term structure debt repayment, interest rate reduction or exemption...

(iv) Taking advantages of innovations using financial technology (Fintech), artificial intelligence (AI)... in operations to reduce operating costs and to mitigate risks.

(v) Strictly following the changes in socio-economic environment and financial markets to make appropriate adjustments of interest rates policies to the market fluctuations and in line with the regulations of the State Bank of Vietnam.

Despite of mentioned contributions, this paper still has limitations such as it could not cover all indicators in the banking industry, and not analyse debt in terms of short-term and long-term. Extending the number of indicators as well as increasing the number of observations will probably increase the reliability of the empirical findings in future studies. 
Acknowledgement: This paper is conducted within the project "Framework for Financial Stability in Vietnam", No. 502.02-2018.16, funded by the National Foundation for Science and Technology Development (NAFOSTED).

\section{REFERENCES}

Abugamea, G. (2018). Determinants of Banking Sector Profitability: Empirical Evidence from Palestine. Journal of Is/amic Economics and Finance, 4(1), 49-67.

Aggarwal, R. and Jacques, K.T. (2001). The impact of FDICIA and prompt corrective action on bank capital and risk: Estimates using a simultaneous equations model. Journal of Banking and Finance, 25(6),1139-1160.

Amidu, M. (2007). Determinants of Capital Structure of Banks in Chaina: An Empirical approach. Baltic Journal of Management, 2(1), 67-79.

Arellano, M. and Bond, S. (1991). Some Tests of Specification for Panel Data: Monte Carlo Evidence and an Application to Employment Equations. The Review of Economic Studies, 58(2), 277.

Arellano, M. and Bover, O. (1995). Another look at the instrumental variable estimation of error-components models. Journal of Econometrics, 68 (1), 29-51.

Aremu, M. A. (2013). Determinants of Capital Structure in Nigerian Banking Sector. International Journal of Academic Research in Economics and Management Sciences, 2(4), 27-43.

Baker, M., and Wurgler, J. (2002). Market timing and capital structure. The journal of finance, 57(1), 1-32.

Bashir, A. H. M. (2003). Determinants of profitability in Islamic banks: Some evidence from the Middle East. Islamic economic studies, 11(1), 73-99.

Berger, A. N., Hasan, I., and Zhou, M. (2010). The effects of focus versus diversification on bank performance: Evidence from Chinese banks. Journal of Banking and Finance, 34(7), 1417-1435.

Bidhari, S. C., Salim, U., Aisjah, S., and Java, E. (2013). Effect of corporate social responsibility information disclosure on financial performance and firm value in banking industry listed at Indonesia stock exchange. European Journal of Business and Management, 5(18), 39-46.

Bikker, J., and Hu, H., (2002). Cyclical patterns in profits, provisioning and lending of banks and procyclicality of the new Basel capital requirements. Banca Nazionale del Lavoro Quarterly Review, 143-175.

Birru, W.M. (2016). The Impact of Capital Structure on Financial Performance of Commercial Banks in Ethiopia. Global Journal of Management and Business Research, 16 (8), 43-52.

Blundell, R. and Bond, S. (1998). Initial conditions and moment restrictions in dynamic panel data models. Journal of Econometrics, 87 (1), 115-143.

Curi, C., Lozano-Vivas, A., and Zelenyuk, V. (2015). Foreign bank diversification and efficiency prior to and during the financial crisis: Does one business model fit all?. Journal of Banking and Finance, 61, S22-S35.

Davydenko, A. (2010). Determinants of bank profitability in Ukraine. Undergraduate Economic Review, 7(1/2), 1-30.

Dawood, U. (2014). Factors impacting profitability of commercial banks in Pakistan for the period of 2009-2012. International Journal of Scientific and Research Publications, 4(3), 1-7.

Demerguç-Kunt A. and H. Huizinga. (1999). Determinants of commercial bank interest margins and profitability: Some international evidence. World Bank Economic Review, 13, 379-408.

Demirgu"c-Kunt, A. and Huizinga, H. (2010). Bank activity and funding strategies: the impact on risk and returns. Journal of Financial Economics, 98 (3), 626-650.

El-Chaarani, H. and El-Abiad, Z. (2019. Analysis of Capital Structure and Performance of Banking Sector in Middle East Countries. International Journal of Economics and Financial Issues, Econjournals, 9(10), 1-11.

Flamini, V., McDonald, C. A., and Schumacher, L. B. (2009). The determinants of commercial bank profitability in Sub-Saharan Africa. IMF Working Papers, 1-30.

Goyal, A. M. (2013). Impact of capital structure on performance of listed public sector banks in India. International journal of business and management invention, 2(10), 35-43.

Hasan, M. B., Ahsan, A. M., Rahaman, M. A., and Alam, M. N. (2014). Influence of capital structure on firm performance: Evidence from Bangladesh. International Journal of Business and Management, 9(5), 184-194.

Hansen, L.P. (1982). Large sample properties of generalized method of moments estimators. Econometrica: Journal of the Econometric Society, 1029-1054. 
Hassan, M. K., and Bashir, A. H. M. (2003, December). Determinants of Islamic banking profitability. In 10th ERF annual conference, Morocco, 7, 2-31.

Hausman, J. A. (1978). Specification Test in Econometrics. Econometrica, 46 (6), 1251-1271. URL http://www.jstor.org/stable/1913827.

Hausman, J. A. and Taylor, W. E. (1981). Panel Data and Unobservable Individual Effects. Econometrica, 49 (6), 1377.

Hawaldar, I. T., Rohit, B., Pinto, P., and Rajesha, T. M. (2017). The impact of oil price crisis on financial performance of commercial banks in Bahrain. Banks and bank systems, 12(4), 4-16.

Hutchison, David E. and Cox, Raymond A. K. (2006). The Causal Relationship Between Bank Capital and Profitability. Annals of Financial Economics, 40-54.

Jensen, M. and Meckling, W. (1976). Theory of the firm: Managerial behavior, agency costs and ownership structure. Journal of Financial Economics 3, 305-360.

Kraus, A. and Litzenberger, R. H. (1973). A State- Preference Model of Optimal Financial Leverge. The Journal of Finance, 28 (4), $911-922$.

Lepetit, L., Nys, E., Rous, P., and Tarazi, A. (2008). The expansion of services in european Banking: Implications for loan pricing and interest margins. Journal of Banking and Finance, 32(11), 2325-2335.

Maudos, J. and Solís, L. (2009). The determinants of net interest income in the mexican banking System: An Integrated model. Journal of Banking and Finance, 33(10), 1920-193.

Modigliani, F. and Miller, M. H. (1958). The Cost of Capital, Corporation Finance and the Theory of Investment. American Economic Review, 48 (3), 261-297.

Modigliani, F. and Miller, M. H. (1963). Corporate Income Taxes and the Cost of Capital: A Correction. The American Economic Review, 53 (3), 433-443.

Moulton, A. (2011). An Investigation of the Determinants and Forecast Performance of Bank Profits: The Case of Jamaican Banks. Research and Economic Programming Division, Bank of Jamaica.

Myers, S. C. (1984). The Capital Structure Puzzle. The Journal of Finance, 39 (3), 574-592.

Myers, S. C., Majluf, N. (1984). Corporate nance and investment decisions when firms have information that investors do not have. Journal of Financial Economics, 13, 187-222.

Naceur, S. (2003). The Determinants of the Tunisian Banking Industry Profitability: Panel Evidence. Universite Libre de Tunis Working Papers, 1-17.

Nguyen, T. C. \& Hoang, N. V. T. (2009). The determinants of commercial banks' financial performance in Vietnam. Journal of Banking Technology, 43 (Octobler 2009), 24-30

Nguyen, T. N. D. \& Nguyen, M. C. (2020). Factors affecting the profitability of Vietnamese commercial banks after mergers and acquisitions. Journal of Commercial Science, 147 (September 2020 2-10, ISSN 1859-3666.

Norden, Lars, and Martin Weber. 2010. Funding modes of German banks: structural changes and their implications. Journal of Financial Services Research 38: 69-93.

Nwude C.E, Anyalechi C.K (2018). Impact of Capital Structure on Performance of Commercial Banks in Nigeria, International Journal of Economics and Financial Issues, 8(2), 298-303.

Ramadan, I., Kilani, Q., and Kaddumi, T (2011). Determinants of Bank Profitability: Evidence from Jordan. International Journal of Academic Research, 3(4),180-191.

Ronoh, C. (2015). Effect of capital structure on financial performance of listed commercial banks in Kenya. A case study of Kenya commercial bank limited, The Strategic Journal of Business and Change Management, 2(72), 750-781.

Obayumi, T. M. (2013). Determinants of Banks' Profitability in a Developing Economy: Evidence from Nigeria. Organizations dnd Markets in Emerging Economies, 4(2/8), 97-111.

Ongore, V. O., and Kusa, G. B. (2013). Determinants of financial performance of commercial banks in Kenya. International journal of economics and financial issues, 3(1), 237-252.

Pinto P. and Quadras, J. M. (2016). Impact of Capital Structure on Financial Performance of Bank, International Journal of Indian Management and Strategy, 21(3), 54-59.

Phan, T. H. \& Phan, T. M. H. (2013). Analysis of factors affecting performance of Vietnamese commercial banks: testing SCP and ES hypotheses. Journal of Economic Development, October, 126-135. 
Porter, R.L. and Chiou, W.J. (2013). How has capital affected bank risk since implementation of the Basel Accords?. Banks and bank systems, $8(1), 63-77$.

Pratomo, W. A., and Ismail, A. G. (2006), Islamic bank performance and capital structure. University Library of Munich, Germany, MPRA, 6012.

Saeed M.M, Gul A.A, and Rasheed Y.M. (2013). Impact of Capital Structure on Banking Performance (A Case Study of Pakistan), Interdisciplinary journal of contemporary research in business, 4(10), 393-403.

San, O. T. and Heng, T. B. (2011). Capital Structure and Corporate Performance of Malaysian Construction Sector, International Journal of Humanities and Social Science, 1(2), pp. 28-36.

Siddik, M., Alam, N., Kabiraj, S., and Joghee, S. (2017). Impacts of capital structure on performance of banks in a developing economy: Evidence from Bangladesh. International journal of financial studies, 5(2), 1-18.

Smirlock, M. (1985). Evidence on the (non) relationship between concentration and profitability in banking. Journal of money, credit and Banking, 17(1), 69-83.

Sufian, F. and Chong, R.R. (2008). Determinants of Bank Profitability in a Developing Economy: Empirical Evidence from the Philippines. Asian Academy of Management Journal of Accounting and Finance, 4(2), 91-112.

Trinugroho, I., Agusman, A., and Tarazi, A. (2014). Why have bank interest margins been so high in Indonesia since the 1997/1998 financial crisis?. Research in International Business and Finance, 32, 139-158.

Zeitun, R., and Tian, G. G. (2007). Does ownership affect a firm's performance and default risk in Jordan?. Corporate Governance: The international journal of business in society, 7 (1), 66-82. 